\title{
Carole Scott \\ Harnessing the monstrous: the dark side of Astrid Lindgren
}

\section{No ordinary girl}

"Pippi was no ordinary girl", (Lindgren 1997, 69) Astrid Lindgren tells us in one of her characteristic ironic understatements. The reader certainly has no quarrel with this observation. Although, unlike Karlsson on the Roof she doesn't have a propeller on her back, Pippi is extraordinary in other ways. Lindgren always begins by describing her strange looks - carrot-red hair in braids that stick out, a nose like a potato, patches on her clothes and unmatched stockings - and her house and its inhabitants - a run-down dwelling in an overgrown garden with a monkey in a straw hat and a horse as roommates. But these outward idiosyncrasies are nothing in comparison with her power and her strength. Able to lift her horse and toss any number of men into the air without effort, she can also walk tightropes or plank bridges suspended in space, run on top of roofs and leap onto trees, ride bareback standing up, climb a tree with a filled coffeepot in her hand, shoot a rifle with unerring accuracy, eat poisonous mushrooms without effect, and steer a ship through storms. "Don't you worry about me. I'll always come out on top", (Lindgren 1997, 3) she informs us.

This little whirlwind is always the center of chaos and destruction. She is certainly a disrupter of conventional life and appropriate behavior, by means of whom Lindgren attacks the petty rules and tyranny that adults too often use to restrain children's joy in life. When Pippi turns Mrs. Rosenblom's tests upside down, giving fine prizes to the children who have failed to win candy or underwear from the unpleasant old woman, Lindgren has her readers applauding Pippi's untrammeled freedom of thought and her determined ignorance, even innocence, of restrictive grown-up expectations. When Pippi greedily grabs cakes and pastries from the tea table, and interrupts 
adult conversation with interminable, far-fetched fictions about her grandmother's imaginary maid Malin, our applause is tempered by the sense that Pippi is a brat, and has gone just too far in breaking all the rules of civilized behavior, even though we can still admire her unrestrainable willfulness and the brash innocence she expresses: "Forgive me because I couldn't behave myself", (Lindgren 1997, 80) she apologizes to Tommy and Annika's mother.

But Lindgren takes Pippi further than this. Her joy in destruction goes way beyond the bratty behavior of the self-indulgent child who delights in the breaking of social convention. Hints of the devilish side of Pippi's nature come early, for example after her total devastation of the school day, the description of Pippi's departure takes on gothic overtones: "with a ringing laugh [she] rode out through the gate so wildly that the pebbles whirled around the horse's hoofs and the window panes rattled in the schoolhouse" (Lindgren 1997, 36). But this characteristic is even more pronounced in her behavior when she rescues two children from a burning house, for she dances "wildly" without fear for her safety, celebrating the fire that has claimed the house and almost two lives, and sings "in a hoarse voice":

\author{
The fire is burning, \\ It's burning so bright, \\ The flames are leaping and prancing. \\ It's burning for you, \\ It's burning for me, \\ It's burning for all who are dancing!
}

As she sang she danced more and more wildly until many people covered their eyes in horror for they were sure she would fall down and kill herself. Flames came leaping out of the gable window, and in the firelight people could see Pippi plainly. She raised her arms to the night sky, and while a shower of sparks fell over her she cried loudly, "Such a jolly, jolly fire!" (Lindgren 1997, 87)

\title{
Monster theory and temporal realities
}

This vision of Pippi as she dances, framed against the flames, reveals her own identification with the destructive power of fire, so that this "most extraordinary child" takes on darker dimensions. In her article "The monster's sacrifice - historic time: The uses of mythic and liminal time in monster literature," K.A. Nazum gathers a range of definitions identifying monsters as "abnormal in form or structure," 
"deviat[ing] from normal or acceptable behavior or character", and "a threatening force." She notes that "monstrous difference [can be] cultural, political, racial, economic, sexual" (Cohen 1996, 7), and that "essentially, any individual or group that can be marginalized or viewed as standing outside the norm may be monstrosized" (Nazum, 208).

As we have seen in Sendak's Where the wild things are and the more recent movie Shrek, monsters are not always terrifying. They can be tamed even when they have threatened to "eat you up", and they can be lovable and have a good sense of humor. In terms of Nazum's collection of definitions, Pippi's visible abnormality is slight, depen-

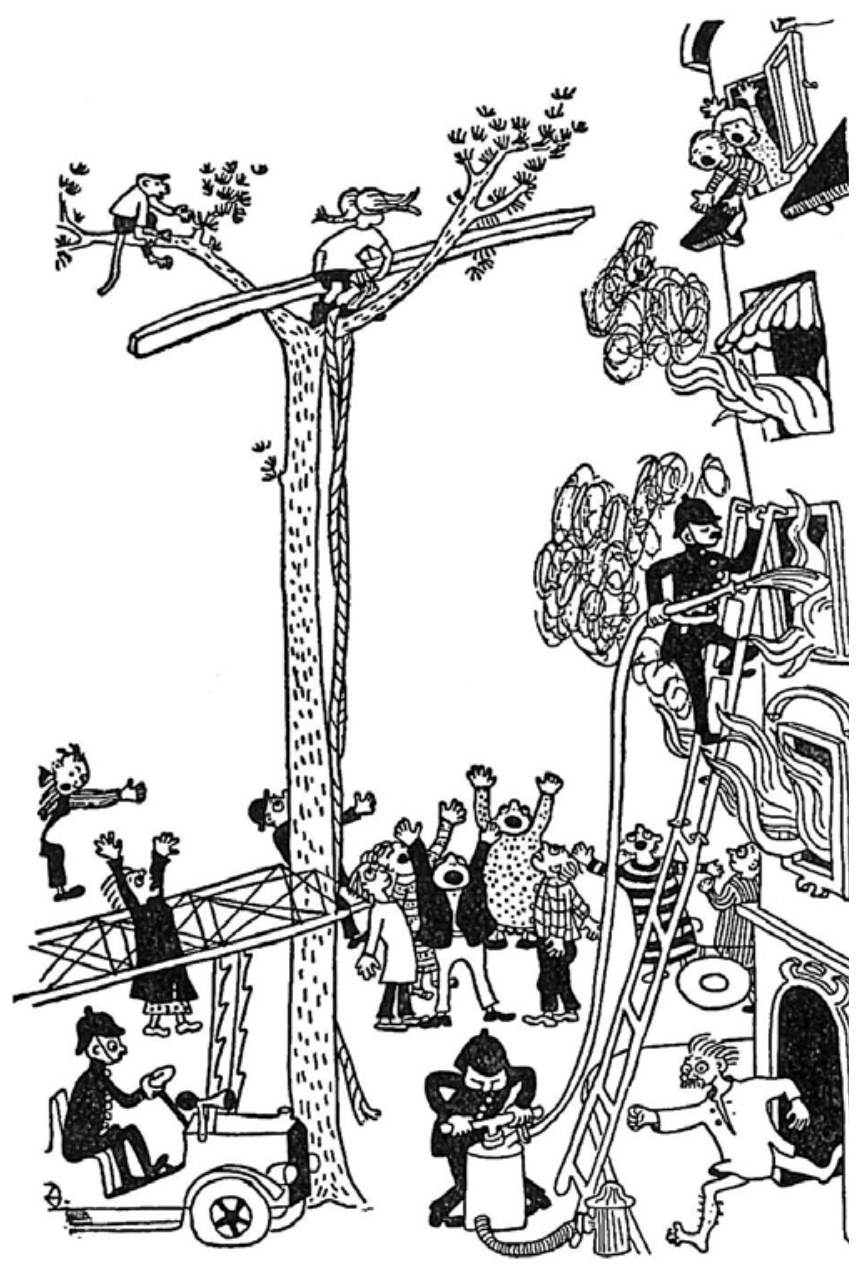

Lindgren, Astrid. Pippi Långstrump. III. Ingrid Vang Nyman. Stockholm: Rabén \& Sjögren, 1966. @ Saltkråkan AB, Lidingö. Bilden återges med tillstånd. (Pippi Longstocking). 
ding on her strange hairstyle and color, her odd face, and her peculiar clothes. She is peculiar or idiosyncratic rather than grotesque. Rather it is the way she acts that obviously "deviates from normal or acceptable behavior or character", and the physical power she wields, though it is generally used for reasonable or moral purposes - removing the horse from the porch when she wants her afternoon coffee, throwing bullies into the air when they hurt other children, and defeating pirates - that makes her "a threatening force". The natural energies of the world, be they gravity, wind, water or fire, are easily managed: not only can she leap and balance high above the ground, she can steer a ship flawlessy though raging storms, she is a perfect shot with either coconuts or rifles, and no one ever goes hungry in her company.

But her mental power is also abnormal. Though she appears in a child's body she is completely independent and self-sufficient. Her perception, wisdom, strategy and persuasiveness are vast, experienced, and abnormal. She "always comes out on top" because she lives in marginal space, and will not submit to physical nor to social restrictions, as she demonstrates from the beginning when the forces of law and order attempt to put her into a home or to educate her. As she herself says when confronted with the fact that the ordinary world has no monsters, "Oh, well, I'll have to be a monster myself, I suppose. I don't see any other way out of it" (Lindgren, 1997, 130). The finale of the Italian film version of Pippi Longstocking features her flying as a witch on a broomstick, a characterization for which Maria Nikolajeva in From mythic to linear has made a well-argued case (Nikolajeva 2000, 116-8).

Nazum believes that "human beings may experience and occupy three temporal realities": linear or historic time; mythic, circular or ritualized time; and liminal or marginal time which is entered in transition from one time frame to another and characterized by dissolution of barriers. Rites of passage and dreaming are both examples of liminal time. Nazum believes that, in contrast to human beings, monsters are unable to exist in historic time, and are thus limited to the mythic and to the liminal spheres.

At the beginning of Pippi goes on board (1946), Lindgren sets her protagonist in a putative world, one outside of ordinary time. "If a stranger should come /--/ he would see Villa Villekulla /--/. If the little girl came to the gate /--/ then he would be able to to take a good look at her /--/. If the stranger went on talking with Pippi, he would learn that Pippi lived all alone" (Lindgren 1997, 103-4). The passage moves to a crescendo with the affirmative, "and nowhere 
in the world, in that town or any other, was there anyone half so strong as she was" (ibid 105). This timeless sphere with its circular, repeatable action is certainly legendary or mythic time. True, Pippi does celebrate birthdays and moves from nine to ten, which is surely an aspect of human, historic time, yet she doesn't seem to change or grow older. And she reserves the right to alter the calendar to her whim, celebrating Christmas when it suits her. Her power over time is finally asserted at the end of the series, in Pippi goes to the South Seas (1948), when she shares the chililug pills with Tommy and Annika, transforming their lives - providing "the strength hadn't gone out of the chililug pills" - so that "the years would go by, but Pippi and Tommy and Annika would not grow up /--/ . There would be new springs and summers, new autumns and winters, but their games would go on" (Lindgren 1997, 282). Not only has Pippi officially shifted her own existence permanently into mythic time, she has taken Tommy and Annika with her. Or is this nostalgic dream for an eternal childhood pertinent in Lindgren's mind only to the "different" or "monstrous" child Pippi, the lonely "Other" who plays out her wishes for company with dried peas?

Shifts from historic to mythic time aside, Pippi, who clearly lives in marginal space, also lives predominantly in marginal or liminal time. Nazum, who credits From mythic to linear as one of her references, characterizes marginal time as transitional and without barriers, a dangerous time where restraints become irrelevant and where the individual may find him or herself without support and vulnerable to extraordinary and life-changing experiences. Pippi is an active force, not only living in marginal time, but creating it for those around her with her destructive and chaotic presence. While related to Bahktin's notion of "carnival", Pippi's knack of turning the world upside down differs in that, for Pippi, this is a constant state, a mode without end, rather than a temporary suspension of ordinary rules. Thus, while she may temporarily introduce carnival into others' lives, she is herself the vector.

\section{Death and denial}

Nazum draws on Kevin McCarron's point that "the primary concern of [adolescent horror fiction] is /--/ death and the fear of death" (McCarron 2001, 21) and concludes that the fear of death is "at the heart of all monster literature and may be understood as the fear of losing one's historical identity, the fear of relinquishing one's place in time". For Pippi, her place in time is barely relevant, and death is 
not frightening because she does not, in her own case, conceive of its power being greater than her own. Lindgren affirms and details Pippi's attitude on several occasions. Besides the devouring of the poisonous toadstool already mentioned, Pippi takes control of the eight bottles of medicine she has purchased, mixes them together and drinks liberally.

\begin{abstract}
Annika, who knew that some of the medicine was to be used only to rub on, was a little worried. "But Pippi," she said, "how do you know that some of that medicine isn't poison?" "I'll find out," said Pippi happily. "I'll find out by tomorrow at the latest. If I'm still alive, then we'll know that it isn't poison and the smallest child can drink it."

Tommy and Annika thought this over. After a while Tommy said doubtfully in a rather frightened voice, "Yes, but what if it is poison? Then what?"

"Then you can have what's left in the bottle to polish the dining-room furniture with," said Pippi. "Poison or not, this meduseen was not bought in vain." (Lindgren 1997, 120)
\end{abstract}

But it is not just her own death that Pippi approaches with apparent nonchalance. When she tells the tale of the Chinese baby who refused to eat the swallow's nest he was served, and starved to death, her insouciance is similar.

"He died. Of Plain Common Ordinary Pigheadedness. The eighteenth of October. And was buried the nineteenth. And on the twentieth a swallow flew in through the window and laid an egg in the nest, which was standing on the table. So it came in handy after all. No harm done" said Pippi happily. (Lindgren 1997, 39-40)

Pippi's remarks suggesting that danger and death are insignificant unrealities unworthy of attention sound very much like Lindgren's own wry comment expressing her own cavalier attitude to death "I don't mind dying, I'll gladly do that, but not right now. I need to clean the house first". Yet this courageous attitude appears in both cases to be covering a deeper understanding of loss, a defiance of death. The Chinese baby story is a tall tale, "You must know that's a lie", says Pippi (Lindgren 1997, 40). In contrast is Pippi's behavior when, playing Monster, she comes across a dead bird. 
[Tommy and Annika] found the Monster sitting on a stone with a very strange expression on its face, looking at something in its hand.

"He's dead. Look, he's absolutely dead," said the Monster. It was a little baby bird that was dead. It had fallen out of the nest and killed itself.

"Oh, what a shame!" said Annika. The Monster nodded.

"Pippi, you're crying", said Tommy suddenly. (Lindgren 1997, 132)

Pippi turns the situation around by denying her tears and her red eyes, but "took the little scrap of a bird and laid it down very carefully on a bed of soft moss. 'If I could, I'd bring you to life again', she said with a deep sigh" (Lindgren 1997, 133).

\section{The darker side}

This revelation that Lindgren provides is just a moment in the comic fantasy that characterizes the Pippi series, a momentary grounding that offers a darker moment in the general grand guignol humor determinedly used to control the harshness of a world where greed and evil threaten. Lindgren's brave face that expresses itself in Pippi's monstrous otherness finds its other mask in such stories of good and evil as The brothers Lionhart (1973) and Mio, my son (1954), where the characters, unlike Pippi, change and grow, experience hunger and pain, and fear death.

Little Rusky in The brothers Lionheart, is in direct contrast to Pippi. He is weak, dependent and fearful. Yet, during the course of the book, he not only faces the passive death that transfers him to be with his brave brother in Nangiyala, he gathers the strength to face death straight on, finally finding the courage to leap over the precipice into darkness, buoyed by the faith that Nangilima awaits them. "I couldn't see the precipice below me, but I knew that it was there, and I needed to take only one step out into the dark and it would all be over /--/ yes, I'm afraid. But I'll do it all the same /--/ " (Lindgren 1975, 183). Jonathan has taught him to shun the easy way that makes a person nothing but "a little bit of filth" and to seek pride in his actions.

While The brothers Lionheart explores the agony of death, regarding with ambivalence the balance of human loss with faith in other realms of existence, the Pippi books set readers rollicking in the wild and funny acts of the outrageous Pippi, distancing death by means of 
Pippi's invulnerability, negating fear with comedy and the firm sense of a power that renders human rules foolish and irrelevant. Despite this cavalier attitude that enables Lindgren to approach death and danger with wry humor, both books offer insights into Lindgren's sense of the dark side of human existence and the strength and courage needed to live a meaningful life in a world of fear, loss and human pettiness, even if it means walking alone.

\section{Bibliography}

Cohen, Jerome Jeffrey. "Monster culture (seven theses)". In Monster theory: reading culture edited by Jerome J. Cohen. Minneapolis: University of Minnesota Press, 1996, 3-25.

Lindgren, Astrid. The brothers Lionheart, trans. Joan Tate. New York: Viking, 1975 [orig. 1973].

Lindgren, Astrid. Mio, my son, trans. Marianne Turner. New York: Viking, 1956 [orig. 1954].

Lindgren, Astrid. The adventures of Pippi Longstocking, trans. Florence Lamborn and Gerry Botham. New York: Viking, 1997 [orig. 1945, 1946, 1948].

McCarron, Kevin. "Point Horror and the point of horror". In Frightening fiction authored by Kimberley Reynolds, Geraldine Brennan and Kevin McCarron. London: Continuum, 2001.

Nazum, K.A. “The monster's sacrifice-historic time: the uses of mythic and liminal time in monster literature". Children's literature association quarterly (29) 3: 207-227.

Nikolajeva, Maria. From mythic to linear. Lanham, Md: Scarecrow, 2000.

Sendak, Maurice. Where the wild things are. New York: HarperCollins, 2000. 